\title{
Thermal effects on failure characteristics of granite with pre-existing fissures
}

\section{Fei Zhao}

Graduate student, School of Resources and Geosciences, China University of Mining and Technology, Xuzhou, People's Republic of China

\section{Qiang Sun}

Professor, Geological Research Institute for Coal Green Mining, Xi'an University of Science and Technology, Xi'an, People's Republic of China (corresponding author: sunqiang04@cumt.edu.cn)

\section{Duoxing Yang}

Professor, Institute of Crustal Dynamics, China Earthquake Administration, Beijing, People's Republic of China

Weiqiang Zhang

Lecturer, School of Resources and Geosciences, China University of Mining and Technology, Xuzhou, People's Republic of China

In order to study the effects of pre-existing fissures on the failure characteristics of granite after high-temperature treatment, granite samples containing three different sets of fissures were heated at different temperatures $\left(100-800^{\circ} \mathrm{C}\right)$, and then a uniaxial compression test was carried out. The major findings are as follows. (a) Temperature and pre-existing fissures have a great influence on the strength of granite. When the temperature is low, the compressive strength exhibits an approximately linear upward relation with increasing $\alpha$ in the range from 30 to $60^{\circ}$. However, with increasing temperature, the effect of pre-existing fissures on the strength of granite decreases, and this trend of growth gradually diminishes. In addition, the thickness of granite samples (from 16 to $29 \mathrm{~mm}$ ) has little effect on the strength of granite in this study. (b) The failure of granite is transformed from brittle to plastic deformation with elevated treatment temperature. In addition, according to failure patterns of granite, there are four crack failure modes under uniaxial pressure. Failure modes I and II occur below $600^{\circ} \mathrm{C}$, and failure modes III and IV mainly occur above $600^{\circ} \mathrm{C}$.

\section{Notation}

$2 a \quad$ length of the fissure $(\mathrm{mm})$

$A \quad$ bearing area $\left(\mathrm{mm}^{2}\right)$

$B_{1}, B_{2}$ brittleness of granite after treatment by high temperature

$d \quad$ width of the fissure (mm)

$h \quad$ thickness of the granite samples (mm)

$P \quad$ peak stress $(\mathrm{kN})$

$T$ treatment temperature $\left({ }^{\circ} \mathrm{C}\right)$

$\alpha \quad$ angle between the fissure and minimum principal stress $\left(^{\circ}\right)$

$\varepsilon_{\mathrm{el}} \quad$ elastic (recoverable) strain

$\varepsilon_{\mathrm{li}} \quad$ absolute irreversible longitudinal strain

$\varepsilon_{\text {tot }} \quad$ total strain at failure

$\sigma_{\mathrm{c}} \quad$ peak strength (MPa)

\section{Introduction}

In recent years, the effect of temperature on rock fracture has been a concern. The properties of rock masses change after exposure to high temperature; this can be applied in many fields, such as stability and safety assessment of rock tunnels and bridges after fires (Ozguven and Ozcelik, 2013; Smith and Pells, 2008; Tang et al., 2017), geothermal energy exploitation (Ogino et al., 1999; Zhao et al., 2011), friction of deep-well drilling and hightemperature-assisted rock breaking (Shafiei and Dusseault, 2013) and storage sites of highly radioactive nuclear waste underground (Emirov et al., 2013; Hudson, 2001; Rutqvist et al., 2005; Wang et al., 2015), which all cause changes in rock properties. Based on the aforementioned applications, many studies have recently researched the influence of temperature and the corresponding changes on the thermal damages and failure mechanical behaviours of rock masses under different temperatures (Brotóns et al., 2013;
Heuze, 1983; Lü et al., 2017; Shen et al., 2019; Sun et al., 2015, 2016; Yang et al., 2017; Yao et al., 2016; Yu et al., 2015; Wu et al., 2013). These researches have pointed out that the peak strength of rock gradually decreases with increasing temperature. In particular, the studies of granite by Chen et al. (2012), Liu and $\mathrm{Xu}$ (2014, 2015), Sun et al. (2015) and Yang et al. (2017) proposed that the compressive strength of granite slowly decreases below $400^{\circ} \mathrm{C}$ and then decreases rapidly, and indicated that the change in the strength of granite samples is related to the damage of the structure caused by thermal reactions.

In fact, different original cracks exist in the rock mass, which also influence the properties of rocks (Lu et al., 2014; Shao et al., 2015; Zhu et al., 2016). Clerici (1990) proposed that the use of a shape tracer combined with a computer provides quick and accurate determination of the fissure roughness. Finn et al. (2003) suggested that a segmented geometry may be used to establish the kinematics of fracture progression in fissure rocks at other scales and in different geologic settings. However, due to the complexity of cracks in rock mass, the influence of internal cracks on rock properties cannot be directly studied. Therefore, previous researchers have treated rocks under laboratory conditions and simulated primary cracks in rocks through the pre-existing fissure or hole method, and the effect of cracks on rock mechanical properties has been further studied (Huang et al., 2017; Wong and Chau, 1998; Wong and Einstein, 2009; Wong et al., 2001, 2002; Yang et al., 2008, 2011, 2012, 2014a, 2014b). Wong and Chau (1998) and Wong et al. (2001) studied crack coalescence in a rocklike material containing two and three cracks. Wong et al. (2002) and Wong and Einstein (2009) studied cracking and failure behaviour in rock samples containing single flaws under uniaxial 
compression. Yang et al. (2011, 2012, 2014a, 2014b) found that the uniaxial compressive strength of a sandstone sample containing a single fissure, two fissures and three fissures exhibits an obvious non-linear relationship with the fissure angle and the strength decreases with the number of fissures. Lu et al. (2014) studied the strength failure and crack coalescence behaviour of sandstone containing a single pre-existing fissure $\left(45^{\circ}\right)$. However, there have been few studies on the combined influences of temperature and ' $\mathrm{X}$ '-type fissures on the mechanical properties of rocks. Therefore, in this study, the effects of temperature and X-type fissures on the compressive strength and failure characteristics of granite were further studied and analysed.

\section{Methods and materials}

Sample preparation and temperature treatment Granite samples with a bulk density of $2.68 \mathrm{~g} / \mathrm{cm}^{3}$ and a water content of $0.03 \%$ were collected from Linyi, Shandong, China. The samples were cut into plate shapes $(160 \mathrm{~mm}$ (length) $\times$

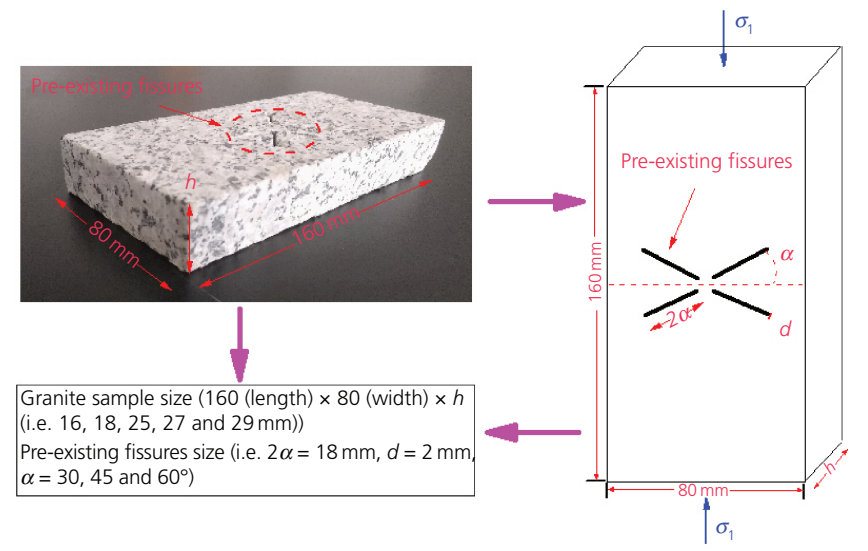

Figure 1. Granite samples confining three sets of fissures
$80 \mathrm{~mm}$ (width)) with five different thickness levels $(16,18,25,27$ and $29 \mathrm{~mm})$. Moreover, the samples were cut with three fissure types $(18 \mathrm{~mm}$ (length) $\times 2 \mathrm{~mm}$ (width)). The total number of granite samples required for the experiment was 210. The samples were heated at seven different temperature levels $(100,300,400$, $500,600,700$ and $800^{\circ} \mathrm{C}$ ) in a furnace (type KSL-1700X) at a rate of $10^{\circ} \mathrm{C} / \mathrm{min}$ and isothermally maintained for $1 \mathrm{~h}$. Then, the samples were cooled to room temperature by air.

\section{Uniaxial compression test}

In this study, according to the stress direction of the rock sample in Figure 1, all samples were tested by a computer-controlled hydraulic universal testing machine (WES-1000D) at a loading rate of $0.5 \mathrm{kN} / \mathrm{s}$. The compressive strength of the samples with pre-existing fissures after different temperature treatments was calculated by using Equation 1, and the failure mode of the samples was analysed.

1. $\sigma_{\mathrm{c}}=\frac{P}{A}$

where $\sigma_{\mathrm{c}}$ is the peak strength $(\mathrm{MPa}) ; P$ is the peak stress $(\mathrm{kN})$; and $A$ is the bearing area $\left(\mathrm{mm}^{2}\right)$.

\section{Results}

Effects of high temperature on granite strength

The test results are shown in Table 1 and Figure 2, and they show that the compressive strength can be divided into two stages with elevated treatment temperature.

- Stage 1 is from 100 to $400^{\circ} \mathrm{C}$. In this stage, the compressive strengths of the granite samples do not change obviously with increasing temperature. As shown in Table 1, when $\alpha=30^{\circ}$, the average compressive strengths of the granite samples with $h=16,18,25,27$ and $29 \mathrm{~mm}$ are $115 \cdot 02,116 \cdot 87,118 \cdot 57$,

Table 1. Average compressive strength values of the granite samples (MPa)

\begin{tabular}{|c|c|c|c|c|c|c|c|c|}
\hline \multirow{2}{*}{$h: \mathrm{mm}$} & \multirow{2}{*}{$\alpha:^{\circ}$} & \multicolumn{7}{|c|}{ Average compressive strength: $\mathrm{MPa}$} \\
\hline & & $100^{\circ} \mathrm{C}$ & $300^{\circ} \mathrm{C}$ & $400^{\circ} \mathrm{C}$ & $500^{\circ} \mathrm{C}$ & $600^{\circ} \mathrm{C}$ & $700^{\circ} \mathrm{C}$ & $800^{\circ} \mathrm{C}$ \\
\hline \multirow[t]{3}{*}{16} & 30 & $115 \cdot 02$ & $105 \cdot 83$ & $92 \cdot 48$ & $75 \cdot 20$ & $59 \cdot 52$ & $54 \cdot 11$ & $27 \cdot 79$ \\
\hline & 45 & $127 \cdot 47$ & $121 \cdot 80$ & 114.65 & $90 \cdot 81$ & $72 \cdot 73$ & $62 \cdot 82$ & 48.69 \\
\hline & 60 & $139 \cdot 01$ & $125 \cdot 17$ & $115 \cdot 32$ & $90 \cdot 64$ & $73 \cdot 77$ & $66 \cdot 22$ & $49 \cdot 72$ \\
\hline \multirow[t]{3}{*}{18} & 30 & $116 \cdot 87$ & $109 \cdot 88$ & $90 \cdot 39$ & $71 \cdot 32$ & 69.74 & 45.92 & 38.24 \\
\hline & 45 & $124 \cdot 36$ & 138.42 & $130 \cdot 37$ & $126 \cdot 32$ & 78.48 & $49 \cdot 48$ & $54 \cdot 64$ \\
\hline & 60 & $151 \cdot 29$ & $142 \cdot 61$ & $140 \cdot 01$ & $135 \cdot 37$ & $87 \cdot 44$ & $54 \cdot 15$ & $59 \cdot 28$ \\
\hline \multirow[t]{3}{*}{25} & 30 & $118 \cdot 57$ & $109 \cdot 95$ & $98 \cdot 55$ & $85 \cdot 81$ & $74 \cdot 02$ & $40 \cdot 16$ & $43 \cdot 97$ \\
\hline & 45 & $141 \cdot 96$ & $147 \cdot 00$ & $136 \cdot 81$ & $124 \cdot 11$ & 84.97 & $60 \cdot 57$ & $48 \cdot 20$ \\
\hline & 60 & $158 \cdot 67$ & $157 \cdot 97$ & $154 \cdot 07$ & $154 \cdot 49$ & $108 \cdot 78$ & $79 \cdot 60$ & 54.00 \\
\hline \multirow[t]{3}{*}{27} & 30 & $123 \cdot 26$ & $136 \cdot 05$ & $132 \cdot 80$ & $129 \cdot 53$ & $86 \cdot 54$ & 54.62 & 38.56 \\
\hline & 45 & $161 \cdot 38$ & $150 \cdot 44$ & $142 \cdot 56$ & $130 \cdot 99$ & $98 \cdot 17$ & $61 \cdot 65$ & 48.98 \\
\hline & 60 & $159 \cdot 57$ & $162 \cdot 06$ & $160 \cdot 80$ & 153.03 & $107 \cdot 50$ & $68 \cdot 88$ & 48.94 \\
\hline \multirow[t]{3}{*}{29} & 30 & $148 \cdot 88$ & $130 \cdot 05$ & $132 \cdot 32$ & $117 \cdot 45$ & $63 \cdot 82$ & $39 \cdot 60$ & $31 \cdot 34$ \\
\hline & 45 & $157 \cdot 62$ & $140 \cdot 33$ & $137 \cdot 68$ & $140 \cdot 45$ & $69 \cdot 33$ & $52 \cdot 80$ & $34 \cdot 11$ \\
\hline & 60 & $173 \cdot 88$ & $148 \cdot 81$ & $150 \cdot 41$ & $147 \cdot 98$ & $85 \cdot 55$ & $66 \cdot 24$ & $40 \cdot 00$ \\
\hline
\end{tabular}




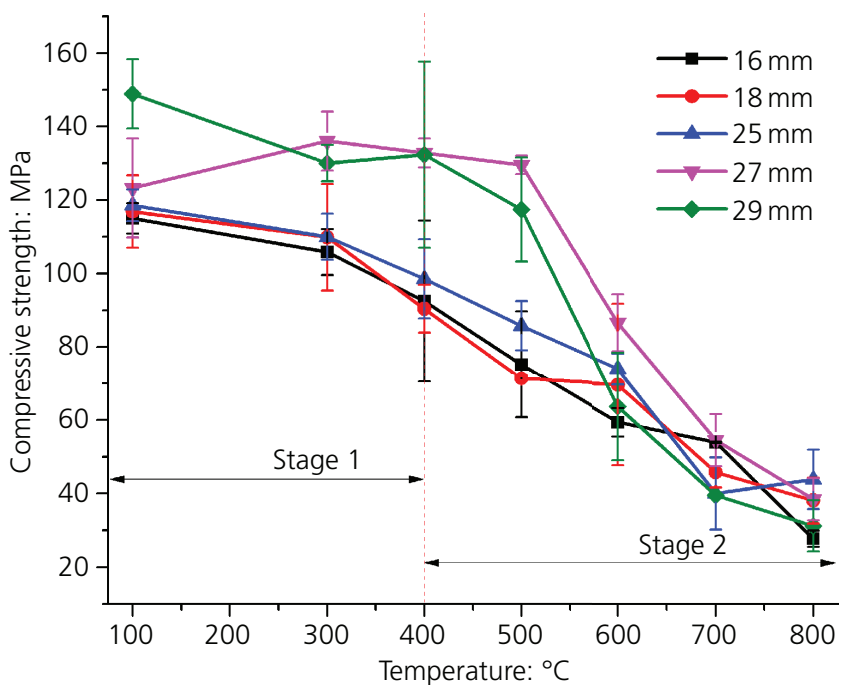

(a)

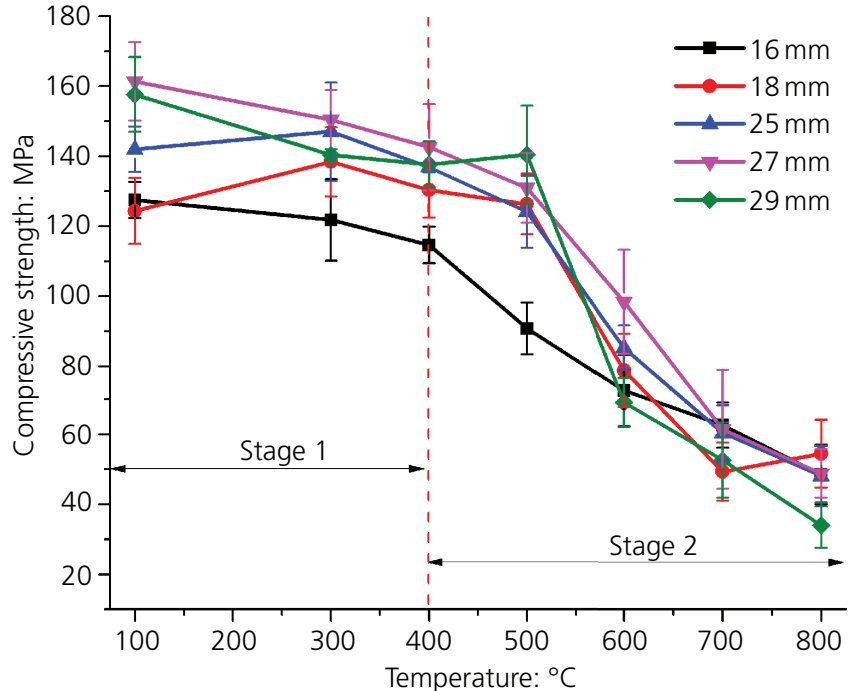

(b)

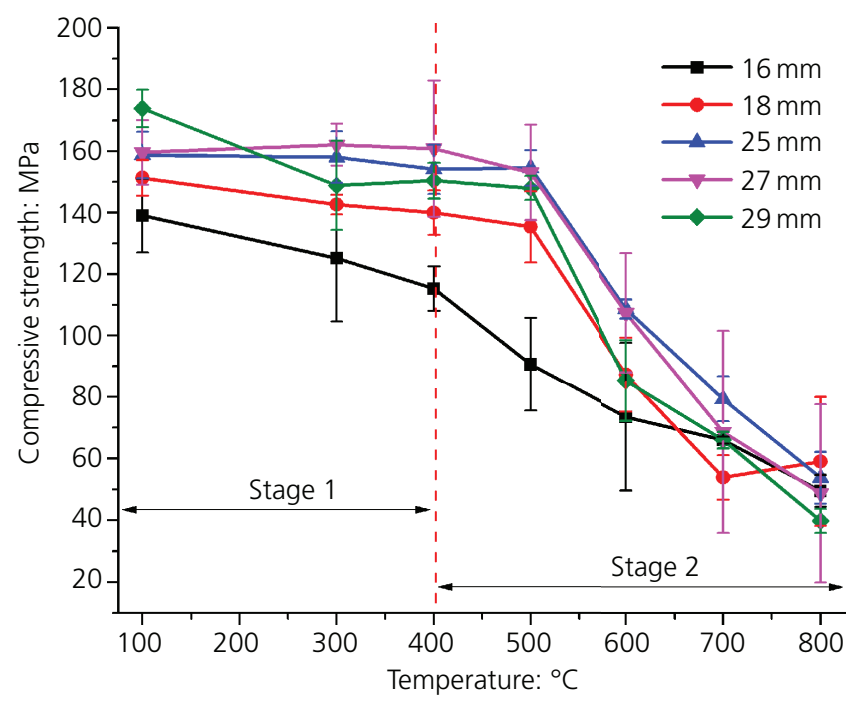

(c)

Figure 2. Compressive strengths of the granite samples with respect to temperature: (a) $\alpha=30^{\circ}$; (b) $\alpha=45^{\circ}$; (c) $\alpha=60^{\circ}$

$123 \cdot 26$ and $148 \cdot 88 \mathrm{MPa}$, respectively, after heating treatment at $100^{\circ} \mathrm{C}$. The average compressive strengths of the granite samples with $h=16,18,25,27$ and $29 \mathrm{~mm}$ are 92.48, 90.39, $98 \cdot 55,132 \cdot 80$ and $132 \cdot 32 \mathrm{MPa}$, respectively, after heating treatment at $400^{\circ} \mathrm{C}$ (as shown in Figure 2(a)). When $\alpha=45^{\circ}$, the average compressive strengths of the granite samples with $h=16,18,25,27$ and $29 \mathrm{~mm}$ are $127 \cdot 41,124 \cdot 36,141 \cdot 96$, $161 \cdot 38$ and $157 \cdot 62 \mathrm{MPa}$, respectively, after heating treatment at $100^{\circ} \mathrm{C}$. The average compressive strengths of the granite samples with $h=16,18,25,27$ and $29 \mathrm{~mm}$ are 114.65, $130 \cdot 37,136 \cdot 81,142 \cdot 56$ and $137 \cdot 68 \mathrm{MPa}$, respectively, after heating treatment at $400^{\circ} \mathrm{C}$ (as shown in Figure 2(b)). When $\alpha=60^{\circ}$, the average compressive strengths of the granite samples with $h=16,18,25,27$ and $29 \mathrm{~mm}$ are $139 \cdot 01$,

$151 \cdot 29,158 \cdot 67,159 \cdot 57$ and $173 \cdot 88 \mathrm{MPa}$, respectively, after heating treatment at $100^{\circ} \mathrm{C}$. The average compressive strengths of the granite samples with $h=16,18,25,27$ and $29 \mathrm{~mm}$ are $115 \cdot 32,140 \cdot 01,154 \cdot 07,160 \cdot 80$ and $150 \cdot 41 \mathrm{MPa}$, respectively, after heating treatment at $400^{\circ} \mathrm{C}$ (as shown in Figure 2(c)).

- Stage 2 is from 400 to $800^{\circ} \mathrm{C}$. During this stage, the compressive strengths of the granite samples decrease rapidly. When $\alpha=30^{\circ}$, the compressive strengths of the granite samples with $h=16,18,25,27$ and $29 \mathrm{~mm}$ decrease to only $27 \cdot 79,38 \cdot 24,43 \cdot 97,38 \cdot 56$ and $31 \cdot 34 \mathrm{MPa}$, respectively, after heating treatment at $800^{\circ} \mathrm{C}$. When $\alpha=45^{\circ}$, the compressive strengths of the granite samples with $h=16,18,25,27$ and $29 \mathrm{~mm}$ decrease to only $48 \cdot 69,54 \cdot 64,48 \cdot 20,48 \cdot 98$ and $34 \cdot 11 \mathrm{MPa}$, respectively, after heating treatment at $800^{\circ} \mathrm{C}$. When $\alpha=60^{\circ}$, the compressive strengths of the granite 
Thermal effects on failure characteristics of granite with pre-existing fissures

Zhao, Sun, Yang and Zhang samples with $h=16,18,25,27$ and $29 \mathrm{~mm}$ decrease to only $49 \cdot 72,59 \cdot 28,54 \cdot 00,48 \cdot 94$ and $40 \cdot 00 \mathrm{MPa}$, respectively, after heating treatment at $800^{\circ} \mathrm{C}$.

\section{Effects of fissures on granite strength}

Figure 3 shows the compressive strengths of the samples with different types of fissures. The results indicate that compressive strength exhibits an upward trend with increasing $\alpha$. The compressive strengths of the granite samples $\left(T=100^{\circ} \mathrm{C}\right.$ and $h=$ $16 \mathrm{~mm})$ first increase from $115 \cdot 02 \mathrm{MPa}\left(\alpha=30^{\circ}\right)$ to $127 \cdot 47 \mathrm{MPa}$ $\left(\alpha=45^{\circ}\right)$ and then to $139 \cdot 01 \mathrm{MPa}\left(\alpha=60^{\circ}\right)$

\section{Effects of thickness on granite strength}

It can be seen from Figure 4 that the curve is approximately parallel in the thickness range $16-27 \mathrm{~mm}$. When the thickness exceeds $27 \mathrm{~mm}$, the curve tends to decrease. The overall change trend is relatively small.

\section{Uniaxial failure characteristics of granite}

Shown in Figure 5 are the stress-deformation curves of the granite samples with different fissures. The results show that the peak stress of granite increases with increase in the fissure angle and that the axial deformation of granite experiences little change with different fissure types.

Figure 6 shows the main failure and crack characteristics of the granite samples (three types of pre-existing fissures) after heat treatments at $100,300,500,600,700$ and $800^{\circ} \mathrm{C}$. When the treatment temperature is between 100 and $600^{\circ} \mathrm{C}$, the sample is broken into large pieces when damaged. The brittle fracture and

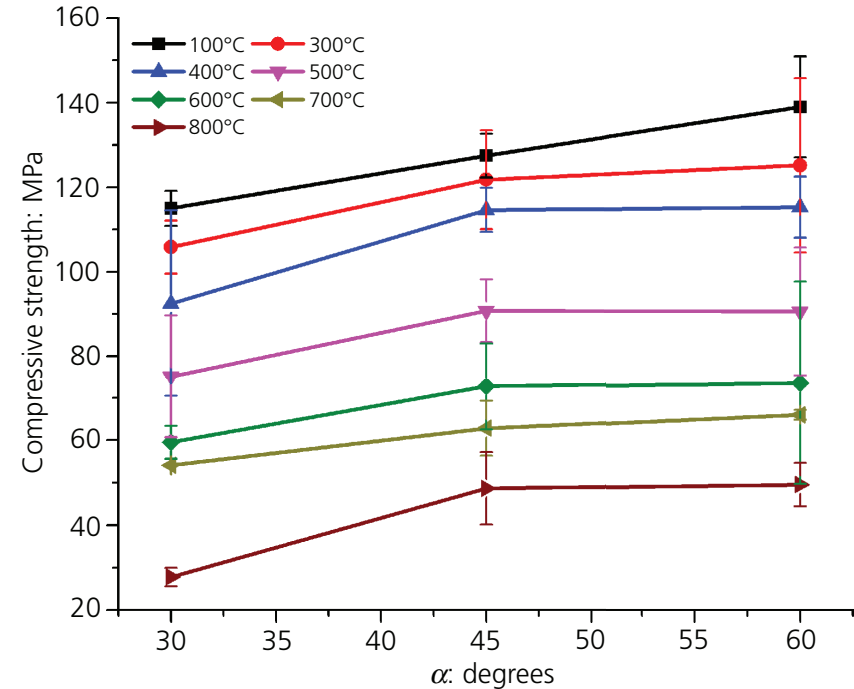

(a)

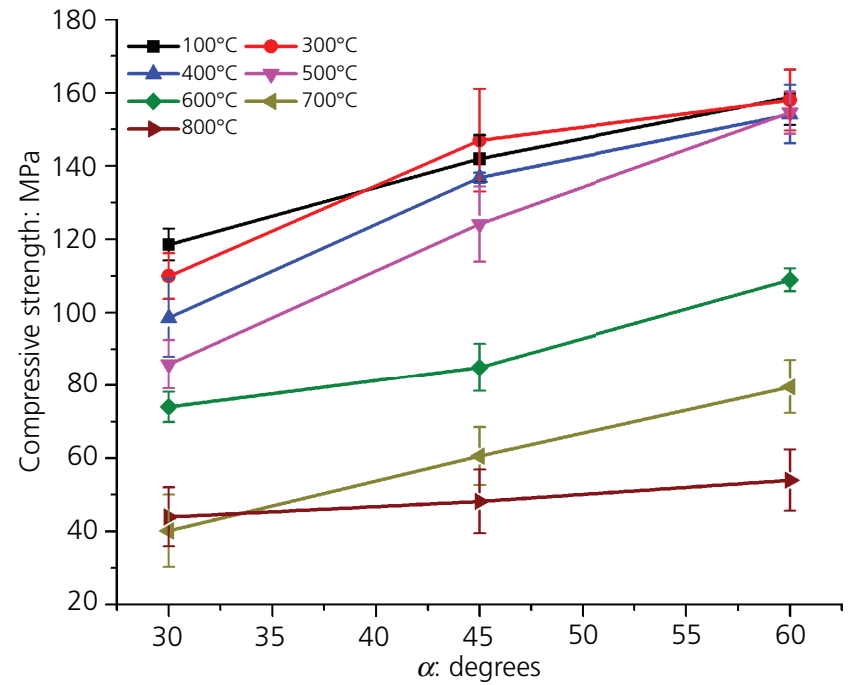

(c)

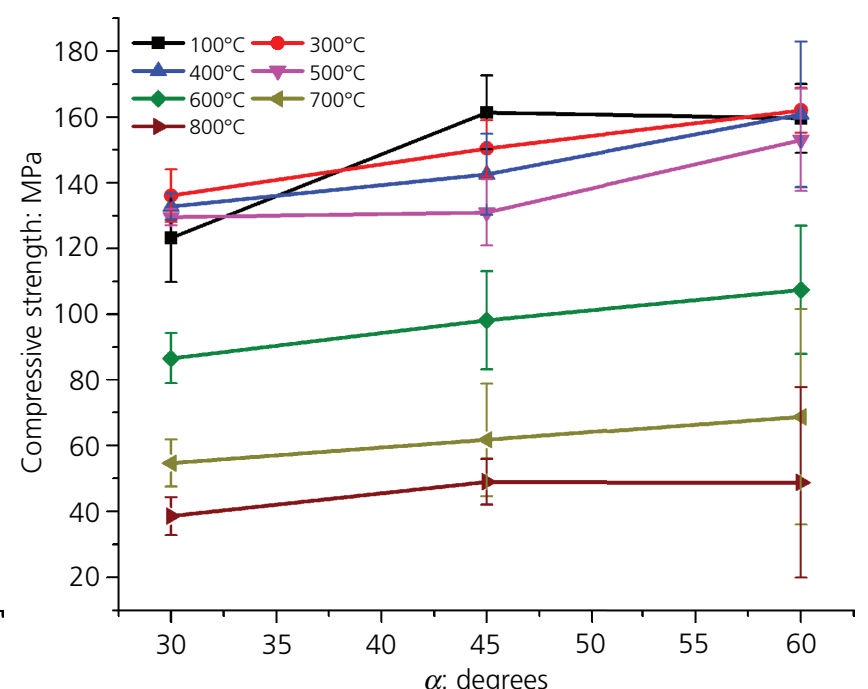

(b)

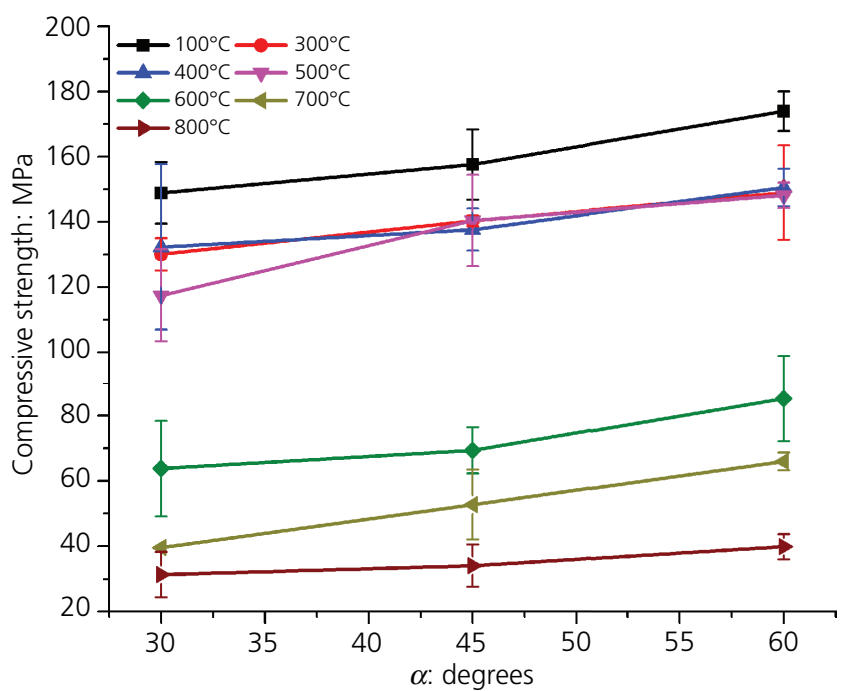

(d)

Figure 3. Compressive strengths of the granite samples with respect to pre-existing fissure angle: (a) $h=16 \mathrm{~mm}$; (b) $h=25 \mathrm{~mm}$; (c) $h=27 \mathrm{~mm}$; (d) $h=29 \mathrm{~mm}$ 


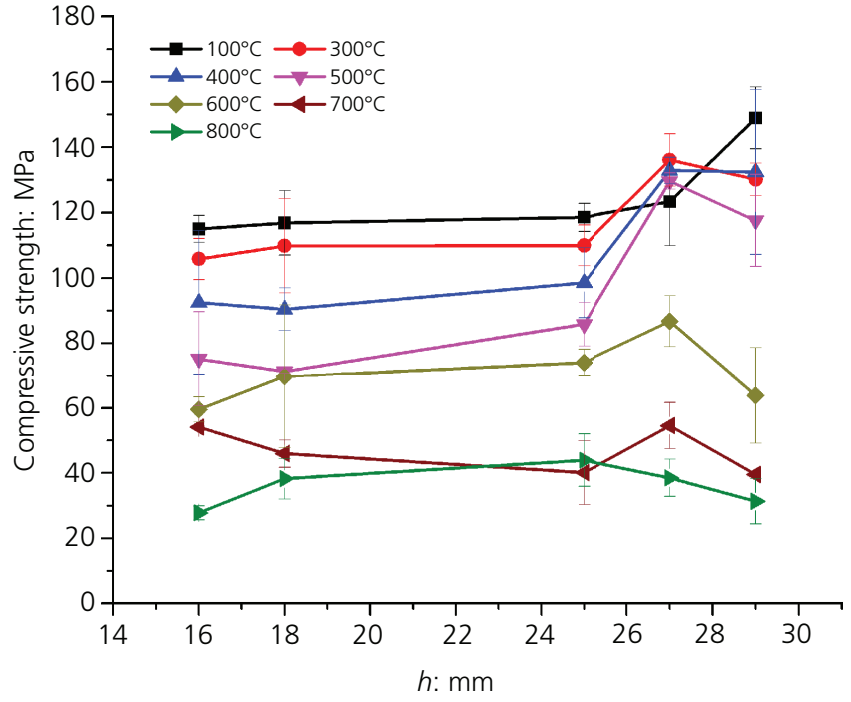

(a)

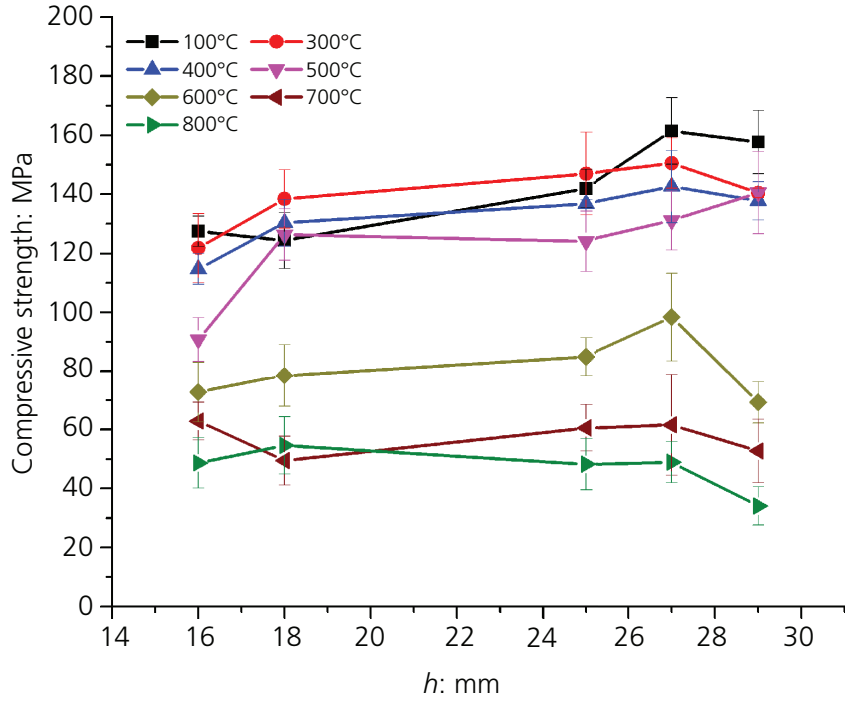

(b)

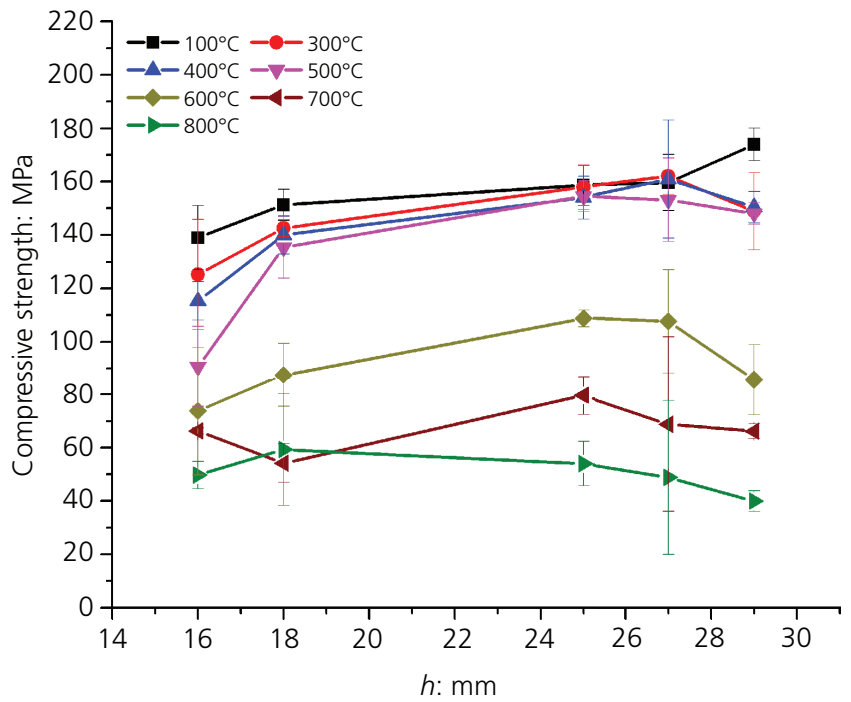

(c)

Figure 4. Relationship between thickness and compressive strength: (a) $\alpha=30^{\circ}$; (b) $\alpha=45^{\circ}$; (c) $\alpha=60^{\circ}$

axial distribution of the rock sample cracks are the main failure features. When the granite samples are heated at $800^{\circ} \mathrm{C}$, at the moment of failure, the sample is broken into large pieces and flaky and granular powder. Moreover, according to failure patterns of granite (Yang et al., 2011, 2014a; Zhang et al., 2019), there are four crack failure modes under uniaxial pressure from Figure 6. In mode I, there are three new cracks, two cracks on both sides passing through pre-existing fissures and a parallel new crack in the middle along the stress direction. In mode II, there are three new cracks, two cracks on both sides not completely passing through pre-existing fissures and a new crack in the middle along the stress direction. In mode III, there are only two new cracks on both sides, which pass through pre-existing fissures. In mode IV, there are only two new cracks, which do not completely pass through pre-existing fissures.

\section{Discussion}

It is known that the mechanical properties of rock are affected by rock shape, rock size, temperature, crack distribution, crack quantity and confining pressure (Heap et al., 2009; Nara and Kaneko, 2006). In this study, the mechanism of the effect of cracks and temperature on the mechanical properties of granite will be analysed as follows.

In this study, the compressive strengths of granite samples decrease with increasing temperature, which has a similar change trend with previous studies (see Figure 7) (Huang et al., 2017; Liu and $\mathrm{Xu}, 2015$; Shao et al., 2015; Sun et al., 2015). In the process of heat treatment, the physical and chemical properties of granite mineral particles change, which leads to changes in the internal structure of granite (Sun et al., 2016; Zhang et al., 2016). 
Thermal effects on failure characteristics of granite with pre-existing fissures

Zhao, Sun, Yang and Zhang

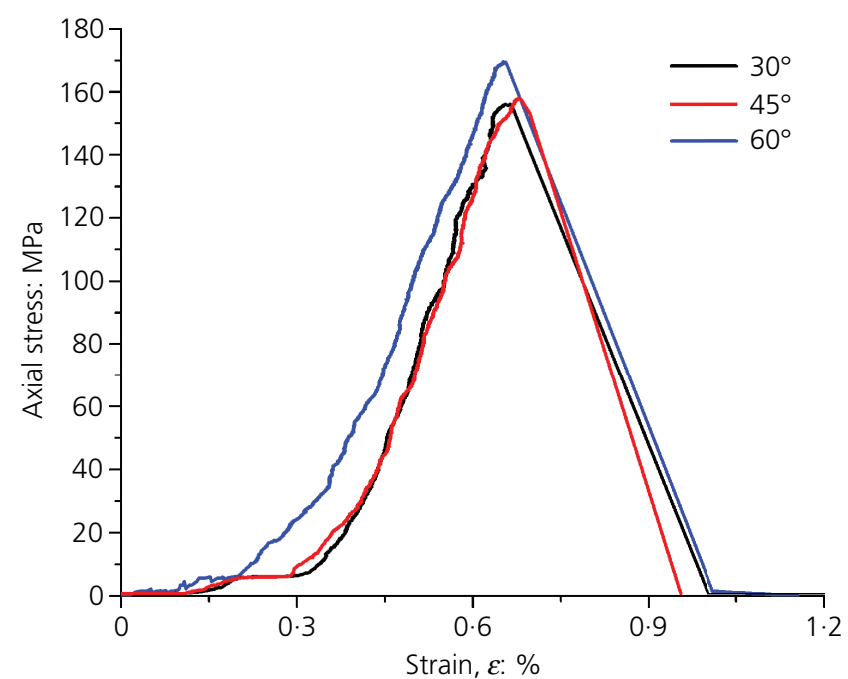

(a)

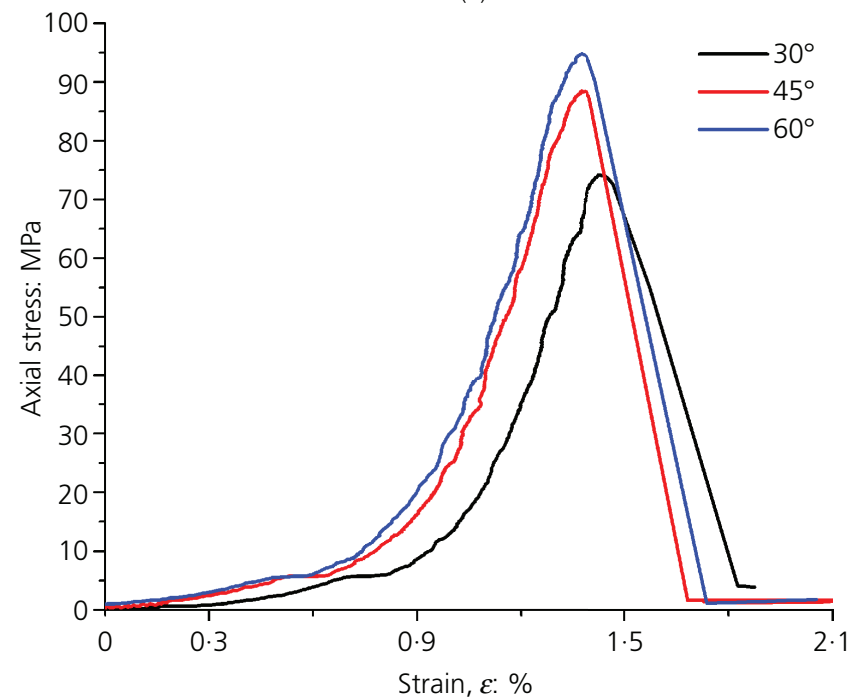

(c)

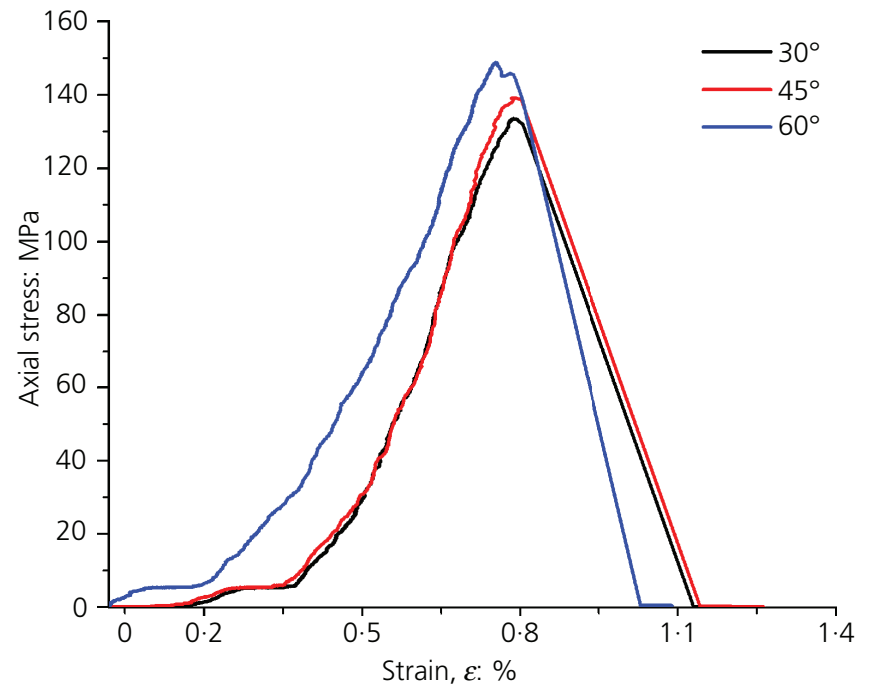

(b)

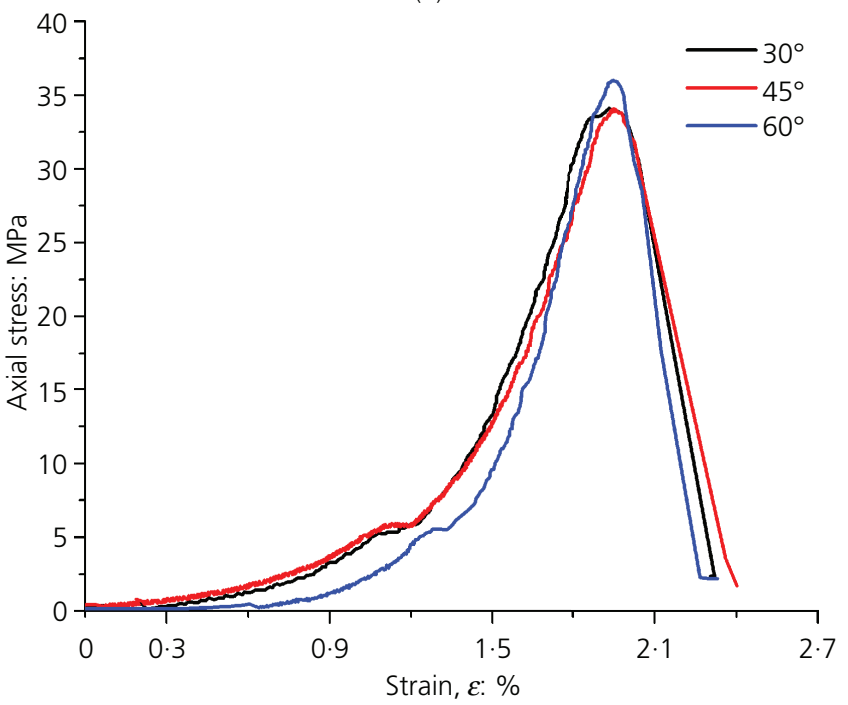

(d)

Figure 5. Stress-deformation curves of heated granite samples (e.g. $h=29 \mathrm{~mm}$ ) with different pre-existing fissures: (a) $100^{\circ} \mathrm{C}$; (b) $300^{\circ} \mathrm{C}$; (c) $600^{\circ} \mathrm{C}$; (d) $800^{\circ} \mathrm{C}$

In this study, the granite sample is mainly composed of quartz, feldspar and hornblende. These minerals have different thermal expansion coefficients, which form a heterogeneous structure in terms of thermal stresses (David et al., 1999; Liu and Xu, 2014; Yoshitaka et al., 2010). With increasing temperature, quartz, feldspar and hornblende exhibit inhomogeneous expansion. When the thermal stress reaches or exceeds the local strength, the maximum thermal stress occurs at the intersection point of the mineral particles, and the connections between the mineral particles are destroyed and microcracks appear and expand (as shown in Figure 8) (Freire-Lista et al., 2016; Griffiths et al., 2017, 2018; Liu and Xu, 2014; Xiao et al., 2018, 2019). In addition, the phase transition of the minerals could also lead to increasing structural defects in the mineral particles. At approximately $573^{\circ} \mathrm{C}$ and atmospheric conditions, quartz is transformed from alpha quartz to beta quartz (as shown in Figure 7) (Somerton and Boozer, 1961). The rapid expansion of mineral particles results in a decrease in compressive strength (Alm, 1985; Sun et al., 2016, 2015). Temperature also leads to change in the brittleness of granite (Chen et al., 2012; Liu and Xu, 2014; Shao et al., 2015; Sun et al., 2015; Tullis and Yund, 1977; Violay et al., 2017; Yang et al., 2017). The brittleness of granite after treatment by high temperature is calculated by using Equations 2 and 3 (Andreev, 1995; Hucka and Das, 1974).

$$
\text { 2. } B_{1}=\frac{\varepsilon_{\mathrm{el}}}{\varepsilon_{\mathrm{tot}}}
$$


Thermal effects on failure characteristics

of granite with pre-existing fissures

Zhao, Sun, Yang and Zhang

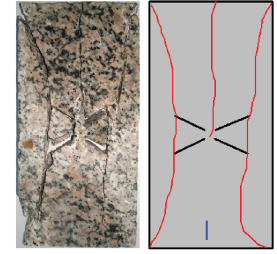

$T=100^{\circ} \mathrm{C}, \alpha=30^{\circ}$

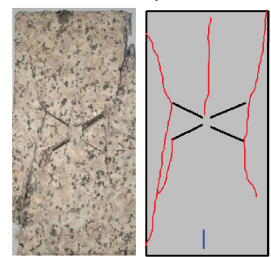

$T=600^{\circ} \mathrm{C}, \alpha=30^{\circ}$

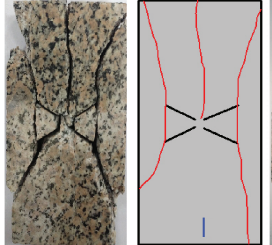

$T=300^{\circ} \mathrm{C}, \alpha=30^{\circ}$

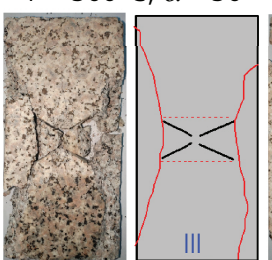

(a)

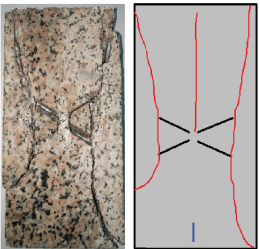

$T=500^{\circ} \mathrm{C}, \alpha=30^{\circ}$

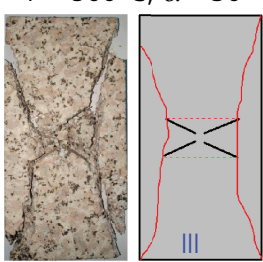

$T=800^{\circ} \mathrm{C}, \alpha=30^{\circ}$
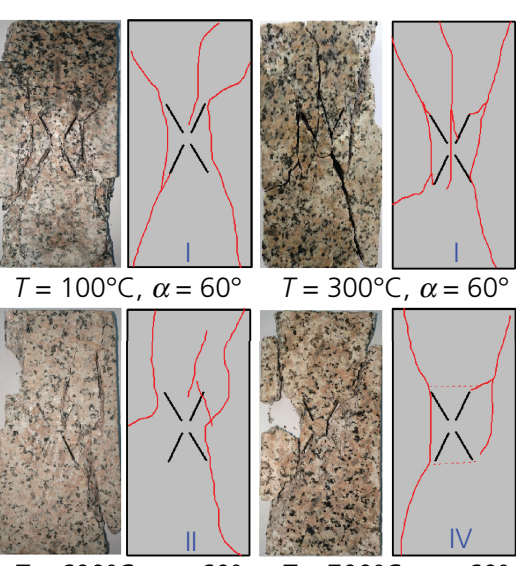

$T=600^{\circ} \mathrm{C}, \alpha=60^{\circ}$

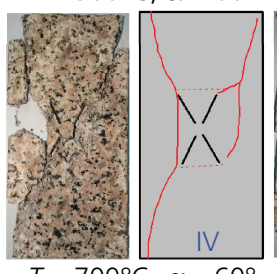

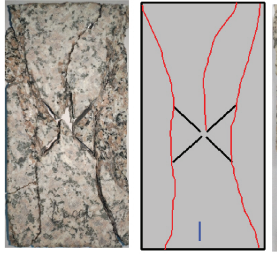
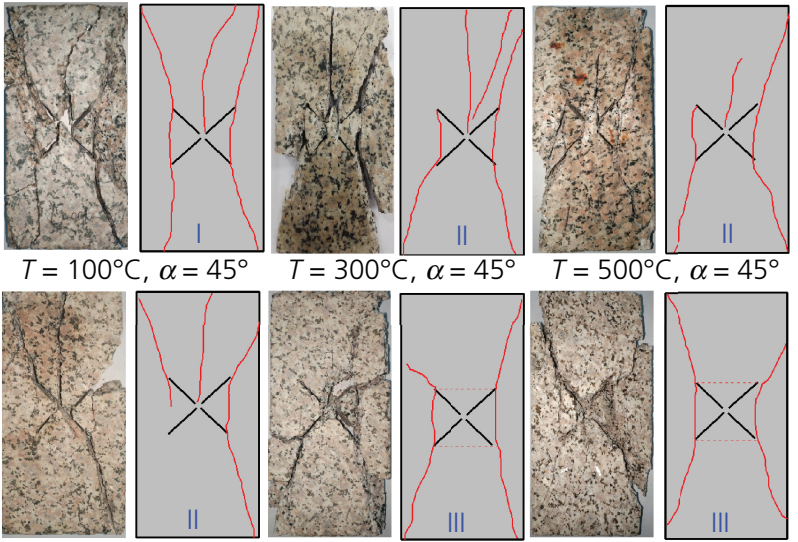

(b)

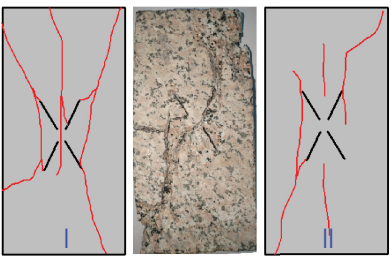

$T=500^{\circ} \mathrm{C}, \alpha=60^{\circ}$

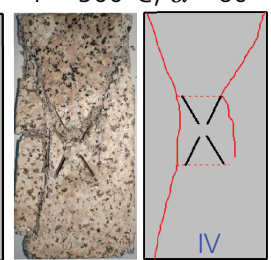

$T=800^{\circ} \mathrm{C}, \alpha=60^{\circ}$

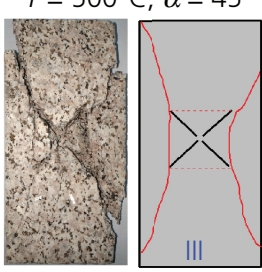

$T=800^{\circ} \mathrm{C}, \alpha=45^{\circ}$

(c)

Figure 6. Uniaxial failure and crack characteristics of granite (e.g. $h=29 \mathrm{~mm}$ ) after high-temperature treatment: (a) $\alpha=30^{\circ}$; (b) $\alpha=45^{\circ}$; (c) $\alpha=60^{\circ}$

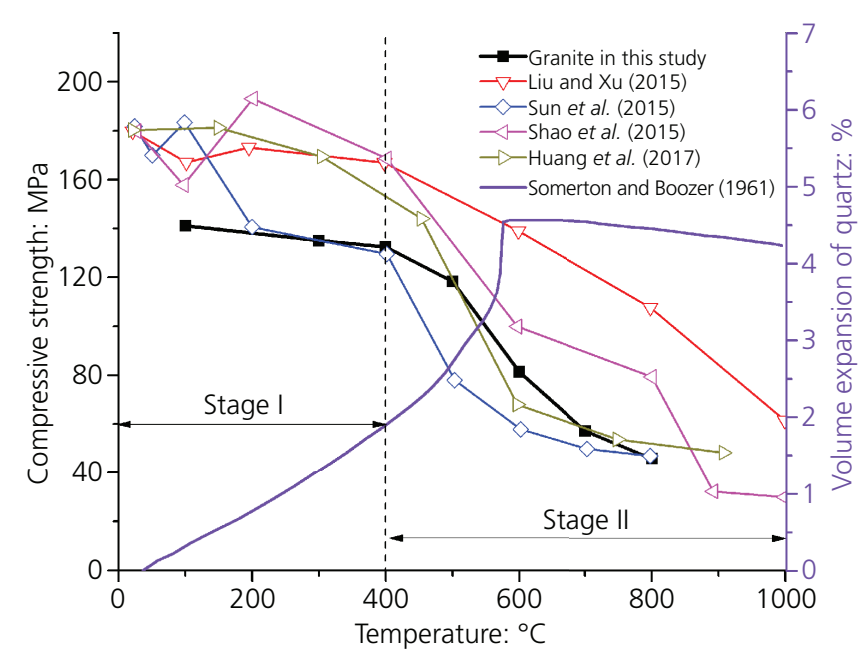

Figure 7. Strengths of the granite samples with increasing temperature: Liu and Xu (2015): $\varnothing 50 \times 100 \mathrm{~mm}$; Sun et al. (2015): $\varnothing 50 \times 100 \mathrm{~mm}$; Shao et al. (2015): $\varnothing 22.5 \times 45 \mathrm{~mm}$; Huang et al. (2017): 160 (length) $\times 80$ (width) $\times 30 \mathrm{~mm}$ (thickness)

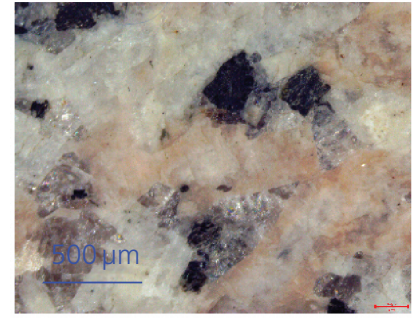

(a)

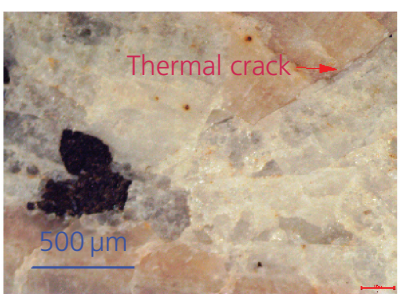

(c)

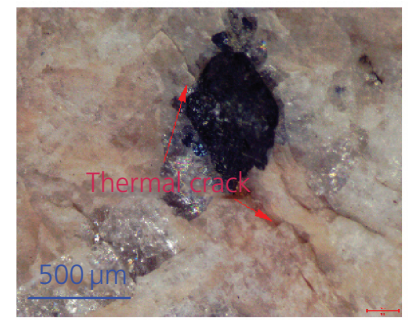

(b)

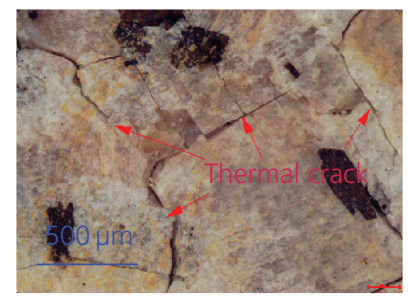

(d)
Figure 8. Thermal cracks on granite surface after different temperature treatments: (a) $100^{\circ} \mathrm{C}$; (b) $400^{\circ} \mathrm{C}$; (c) $600^{\circ} \mathrm{C}$; (d) $800^{\circ} \mathrm{C}$ 
where $\varepsilon_{\mathrm{el}}$ is the elastic (recoverable) strain and $\varepsilon_{\text {tot }}$ is the total strain at failure.

3. $B_{2}=\varepsilon_{\mathrm{li}} \times 100 \%$

where $\varepsilon_{\mathrm{li}}$ is the absolute irreversible longitudinal strain.

As shown in Figure 9, the brittleness of granite decreases with increasing temperature. Therefore, it is inferred that the failure of granite in a uniaxial compression experiment results in transformation from brittle to plastic deformation with increasing temperature.

Fissures have a great influence on the strength of granite in a uniaxial compression test. It is obvious that the compressive stress exhibits an approximately linear upward relation with increasing $\alpha$ in the range from 30 to $60^{\circ}$ (as shown in Figure 3). However, previous studies (Yang et al., 2011, 2014a) investigated the effect of different angle fissures on sandstone strength by prefabricating two kinds of single fissures, which showed a variation between these parameters different from the variation shown in the current study. Without considering the effects of temperature, the authors of the previous studies showed that the compressive strength of sandstone containing a single fissure has a non-linear relationship with the fissure angle in the range from 15 to $75^{\circ}$ (see Figure 10). The comparison between previous studies and this study shows that the strength variation and uniaxial failure characteristics of single-fissure rocks are different from those of Xtype fissure rocks in this study.

This study found temperature and fissures have a common effect on the failure pattern of granite (see Table 2). When the temperature is lower, the influence of the fissures on the failure mode of granite is particularly prominent, which mainly causes failure modes I and II. When the temperature increases, the temperature becomes the dominant factor affecting the properties of granite. The higher the temperature is, the more serious the

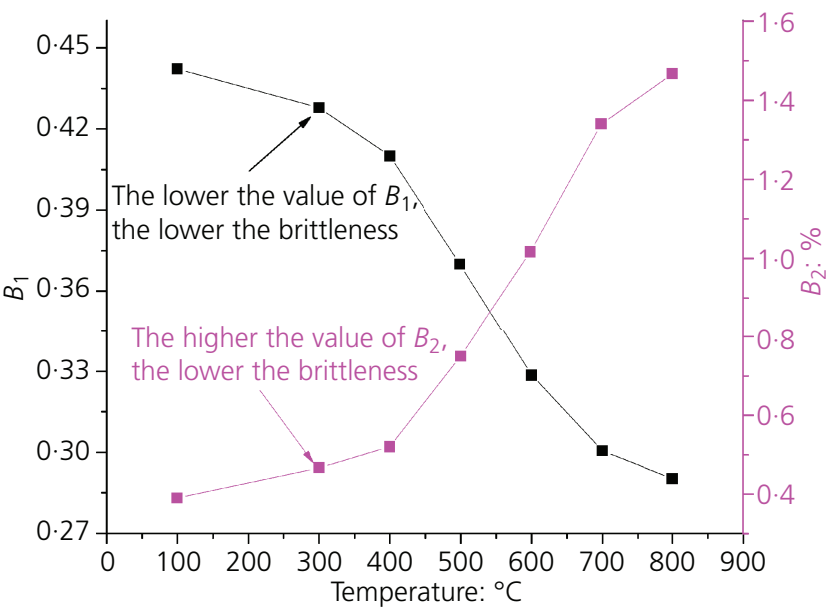

Figure 9. Brittleness of granite treated by different temperatures

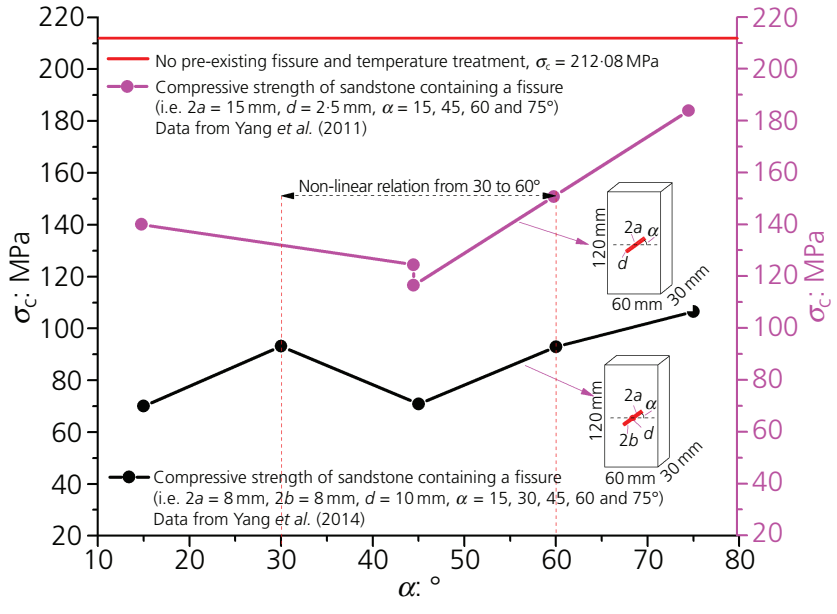

Figure 10. Compressive strength of rock samples containing a fissure: Yang et al. (2011): single fissure with $2 a=15 \mathrm{~mm}$, $d=2.5 \mathrm{~mm}$ and $\alpha=15,45,60$ and $75^{\circ}$; Yang et al. (2014a): single fissure with $2 a=8 \mathrm{~mm}, 2 b=8 \mathrm{~mm}, d=10 \mathrm{~mm}$ and $\alpha=15,30,45,60$ and $75^{\circ}$

Table 2. Four crack failure modes of heated granite samples (e.g. $h=29 \mathrm{~mm}$ ) under uniaxial pressure

\begin{tabular}{ccccccc}
\multicolumn{7}{c}{ Failure mode } \\
$\alpha:^{\circ}$ & $100^{\circ} \mathrm{C}$ & $300^{\circ} \mathrm{C}$ & $500^{\circ} \mathrm{C}$ & $600^{\circ} \mathrm{C}$ & $700^{\circ} \mathrm{C}$ & $800^{\circ} \mathrm{C}$ \\
\hline 30 & I & I & I & I & III & III \\
45 & I & II & II & II & III & III \\
60 & I & I & II & II & IV & IV
\end{tabular}

damage to the rock mass around the pre-existing fissure. Under high-temperature treatment, pre-existing fissures are more likely to lead to the further development of internal fissures in granite (David et al., 2012; Freire-Lista et al., 2016; Sun et al., 2015; Wang et al., 2015). The rock mass around the fissure is more easily damaged in the process of uniaxial compression. There are mainly failure modes III and IV above $600^{\circ} \mathrm{C}$. Therefore, the temperature of $600^{\circ} \mathrm{C}$ can be considered as the threshold for the change in failure characteristics. In summary, fissures and temperature have important effects on the failure pattern of granite samples.

\section{Conclusions}

In this study, in order to study the combined effects of temperature, pre-existing fissures and thickness on the compressive strengths of granite samples, high-temperature tests and uniaxial compression tests were carried out on granite samples of different thicknesses with pre-existing fissures. The major findings are as follows.

- Temperature and pre-existing fissures have a great influence on the strength of granite. When the temperature is low, the compressive strength exhibits an approximately linear upward relation with increasing $\alpha$ in the range from 30 to $60^{\circ}$.

However, with increasing temperature, the influence of pre- 
existing fissures on the strength of granite decreases and this trend of growth gradually diminishes. In addition, the thickness of granite samples (from 16 to $29 \mathrm{~mm}$ ) has little effect on the strength of granite in this study.

- The failure of granite is transformed from brittle to plastic deformation with elevated treatment temperature. In addition, according to failure patterns of granite, there are four crack failure modes under uniaxial pressure. Failure modes I and II occur below $600^{\circ} \mathrm{C}$, and failure modes III and IV mainly occur above $600^{\circ} \mathrm{C}$

\section{Acknowledgements}

This research was supported by the National Natural Science Foundation of China (grants 41672279, 41874113 and 41807233) and the Natural Science Foundation of Jiangsu Province (grant BK20180662). The authors would also like to thank the technicians who helped them during the experiment.

\section{REFERENCES}

Alm $O$ (1985) The influence of micro crack density on the elastic and fracture mechanical properties of stropa granite. Physics of the Earth and Planetary Interiors 40(3): 161-179, https://doi.org/10.1016/00319201(85)90127-x.

Andreev GE (1995) Brittle Failure of Rock Materials. CRC Press, Boca Raton, FL, USA.

Brotóns V, Tomás R, Ivorra S and Alarcón JC (2013) Temperature influence on the physical and mechanical properties of a porous rock: San Julian's calcarenite. Engineering Geology 167: 117-127, https://doi. org/10.1016/j.enggeo.2013.10.012.

Chen YL, Ni J, Shao W and Azzam R (2012) Experimental study on the influence of temperature on the mechanical properties of granite under uniaxial compression and fatigue loading. International Journal of Rock Mechanics and Mining Sciences 56: 62-66, https://doi.org/10. 1016/j.jirmms.2012.07.026.

Clerici A (1990) Some remarks on shear strength measurement along fissures in rocks with a rigid behavior. Bulletin of the International Association of Engineering Geology 41(1): 57-62, https://doi.org/10. 1007/BF02590207.

David C, Menéndez B and Darot M (1999) Influence of stress-induced and thermal cracking on physical properties and microstructure of La Peyratte granite. International Journal of Rock Mechanics and Mining Sciences 36(4): 433-448, https://doi.org/10.1016/S0148-9062(99)00010-8.

David EC, Brantut N, Schubnel A and Zimmerman RW (2012) Sliding crack model for nonlinearity and hysteresis in the uniaxial stress-strain curve of rock. International Journal of Rock Mechanics and Mining Sciences 52: 9-17, https://doi.org/10.1016/j.ijrmms.2012.02.001.

Emirov SN and Ramazanova AE (2013) Experimental study of heat transfer on the borders of grains in ordered and disordered media. Bulletin of the Russian Academy of Sciences: Physics 77(3): 284-287, https://doi.org/10.3103/S1062873813030106.

Freire-Lista DM, Fort R and Varas MJ (2016) Thermal stress-induced microcracking in building granite. Engineering Geology 206: 83-93, https://doi.org/10.1016/j.enggeo.2016.03.005.

Finn MD, Gross MR, Eyal Y and Draper G (2003) Kinematics of throughgoing fractures in jointed rocks. Tectonophysics 376(3-4): 151-166, https://doi.org/10.1016/j.tecto.2003.10.001.

Griffiths L, Heap MJ, Baud P and Schmittbuhl J (2017) Quantification of microcrack characteristics and implications for stiffness and strength of granite. International Journal of Rock Mechanics and Mining Sciences 100: 138-150, https://doi.org/10.1016/j.ijrmms.2017.10.013.
Griffiths L, Lengliné O, Heap MJ, Baud P and Schmittbuhl J (2018) Thermal cracking in Westerly Granite monitored using direct wave velocity, coda wave interferometry, and acoustic emissions. Journal of Geophysical Research: Solid Earth 123(3): 2246-2261, https:/doi.org/ 10.1002/2017JB015191.

Heap MJ, Baud P and Meredith PG (2009) Influence of temperature on brittle creep in sandstones. Geophysical Research Letters 36(19): 115-125, https://doi.org/10.1029/2009g1039373.

Heuze FE (1983) High temperature mechanical, physical and thermal properties of granitic rocks - a review. International Journal of Rock Mechanics and Mining Sciences 20(1): 3-10, https://doi.org/10.1016/ 0148-9062(83)91609-1.

Huang YH, Yang SQ, Tian WL et al. (2017) Physical and mechanical behavior of granite containing pre-existing holes after high temperature treatment. Archives of Civil and Mechanical Engineering 17(4): 912-925, https://doi.org/10.1016/j.acme.2017.03.007.

Hucka V and Das B (1974) Brittleness determination of rocks by different methods. International Journal of Rock Mechanics and Mining Sciences: Geomechanics Abstracts 11(10): 389-392, https://doi.org/ 10.1016/0148-9062(74)91109-7.

Hudson JA (2001) Coupled T-H-M issues relating to radioactive waste repository design and performance. International Journal of Rock Mechanics and Mining Sciences 38(1): 143-161, https://doi.org/10. 1016/S1365-1609(00)00070-8.

Liu S and Xu J (2014) Mechanical properties of Qinling biotite granite after high temperature treatment. International Journal of Rock Mechanics and Mining Sciences 71: 188-193, https://doi.org/10.1016/ j.ijrmms.2014.07.008.

Liu S and Xu J (2015) An experimental study on the physico-mechanical properties of two post-high-temperature rocks. Engineering Geology 185: 63-70, https://doi.org/10.1016/j.enggeo.2014.11.013.

Lu Z, Chen X and Feng X (2014) Strength failure and crack coalescence behavior of sandstone containing single pre-cut fissure under coupled stress, fluid flow and changing chemical environment. Journal of Central South University 21(3): 1176-1183, https://doi.org/10.1007/ s11771-014-2051-z.

Lü C, Sun Q, Zhang W, Geng J and Lu L (2017) The effect of high temperature on tensile strength of sandstone. Applied Thermal Engineering 111: 573-579, https://doi.org/10.1016/j.applthermaleng. 2016.09.151.

Nara Y and Kaneko K (2006) Sub-critical crack growth in anisotropic rock. International Journal of Rock Mechanics and Mining Sciences 43(3): 437-453, https://doi.org/10.1016/j.ijrmms.2005.07.008.

Ogino F, Yamamura M and Fukuda T (1999) Heat transfer from hot dry rock to water flowing through a circular fracture. Geothermics $\mathbf{2 8 ( 1 ) :}$ 21-44, https://doi.org/10.1016/s0375-6505(98)00043-1.

Ozguven A and Ozcelik Y (2013) Investigation of some property changes of natural building stones exposed to fire and high heat. Construction and Building Materials 38: 813-821, https://doi.org/10.1016/j. conbuildmat.2012.09.072.

Rutqvist J, Barr D, Datta R et al. (2005) Coupled thermal-hydrological-mechanical analyses of the Yucca Mountain Drift Scale Test - comparison of field measurements to predictions of four different numerical models. International Journal of Rock Mechanics and Mining Sciences 42(5): 680-697, https://doi.org/10. 1016/j.ijrmms.2005.03.008.

Shafiei A and Dusseault MB (2013) Geomechanics of thermal viscous oil production in sandstones. Journal of Petroleum Science and Engineering 103: 121-139, https://doi.org/10.1016/j.petrol.2013.02.001.

Shao S, Ranjitha PG, Wasantha PLP and Chen BK (2015) Experimental and numerical studies on the mechanical behaviour of Australian Strathbogie granite at high temperatures: an application to geothermal energy. Geothermics 54: 96-108, https://doi.org/10.1016/j. geothermics.2014.11.005. 
Shen Y, Wang Y, Yang Y et al. (2019) Influence of surface roughness and hydrophilicity on bonding strength of concrete-rock interface. Construction and Building Materials 213: 156-166, https://doi.org/10. 1016/j.conbuildmat.2019.04.078.

Smith AG and Pells PJN (2008) Impact of fire on tunnels in Hawkesbury sandstone. Tunnelling and Underground Space Technology 23(1) 65-74, https://doi.org/10.1016/j.tust.2006.11.003.

Somerton WH and Boozer GD (1961) A method of measuring thermal diffusivities of rocks at elevated temperatures. AIChE Journal 7(1) 87-90, https://doi.org/10.1002/aic.690070121.

Sun Q, Zhang W, Xue L, Zhang Z and Su T (2015) Thermal damage pattern and thresholds of granite. Environmental Earth Sciences 74(3): 2341-2349, https://doi.org/10.1007/s12665-015-4234-9.

Sun Q, Lü C, Cao L et al. (2016) Thermal properties of sandstone after treatment at high temperature. International Journal of Rock Mechanics and Mining Sciences 85: 60-66, https://doi.org/10.1016/j. ijrmms.2016.03.006.

Tang X, Wang M, Dong C, Tong J and Wang Y (2017) Sensitivity analysis for shear strength of flat interface between shotcrete and granite in high temperature tunnel. In 4th International Conference on Renewable Energy and Environmental Technology (ICREET 2016) (Kim YH (ed.)). Atlantis Press, Amsterdam, the Netherlands, pp. 155-160.

Tullis J and Yund RA (1977) Experimental deformation of dry Westerly granite. Journal of Geophysical Research 82(36): 5705-5718, https:// doi.org/10.1029/jb082i036p05705.

Violay M, Heap MJ, Acosta M and Madonna C (2017) Porosity evolution at the brittle-ductile transition in the continental crust: implications for deep hydro-geothermal circulation. Scientific Reports 7(1): article 7705, https://doi.org/10.1038/s41598-017-08108-5.

Wang LL, Bornert M, Yang DS et al. (2015) Microstructural insight into the nonlinear swelling of argillaceous rocks. Engineering Geology 193: 435-444, https://doi.org/10.1016/j.enggeo.2015.05.019.

Wong RHC and Chau KT (1998) Crack coalescence in a rock-like material containing two cracks. International Journal of Rock Mechanics and Mining Sciences 35(2): 147-164, https://doi.org/10.1016/S0148-9062 (97)00303-3.

Wong LNY and Einstein HH (2009) Systematic evaluation of cracking behavior in samples containing single flaws under uniaxial compression. International Journal of Rock Mechanics and Mining Sciences 46(2): 239-249, https://doi.org/10.1016/j.ijrmms.2008.03. 006.

Wong RHC, Chau KT, Tang CA and Lin P (2001) Analysis of crack coalescence in rock-like materials containing three flaws - part I: experimental approach. International Journal of Rock Mechanics and Mining Sciences 38(7): 909-924, https://doi.org/10.1016/S1365-1609 (01)00064-8.

Wong RHC, Tang CA, Chau KT and Lin P (2002) Splitting failure in brittle rocks containing pre-existing flaws under uniaxial compression. Engineering Fracture Mechanics 69(17): 1853-1871, https://doi.org/ 10.1016/s0013-7944(02)00065-6.

Wu G, Wang Y, Swift G and Chen J (2013) Laboratory Investigation of the effects of temperature on the mechanical properties of sandstone. Geotechnical and Geological Engineering 31(2): 809-816, https://doi. org/10.1007/s10706-013-9614-X.

Xiao Y, Liu H, Nan B and McCartney JS (2018) Gradation-dependent thermal conductivity of sands. Journal of Geotechnical and Geoenvironmental Engineering 144(9): article 06018010, https://doi. org/10.1061/(ASCE)GT.1943-5606.0001943.

Xiao Y, Nan BW and McCartney JS (2019) Thermal conductivity of sand-tire shred mixtures. Journal of Geotechnical and Geoenvironmental Engineering 145(11): article 06019012, https://doi. org/10.1061/(ASCE)GT.1943-5606.0002155

Yang SQ, Jiang YZ, Xu WY and Chen XQ (2008) Experimental investigation on strength and failure behavior of pre-cracked marble under conventional triaxial compression. International Journal of
Solids and Structures 45(17): 4796-4819, https://doi.org/10.1016/j. ijsolstr.2008.04.023.

Yang SQ, Jing HW and Xu T (2011) Strength failure and crack coalescence behavior of brittle sandstone samples containing a single fissure under uniaxial compression. International Journal of Fracture 168(2): 227-250, https://doi.org/10.1007/s10704-010-9576-4.

Yang SQ, Yang DS, Jing HW, Li YH and Wang SY (2012) An experimental study of the fracture coalescence behaviour of brittle sandstone samples containing three fissures. Rock Mechanics and Rock Engineering 45(4): 563-582, https://doi.org/10.1007/s00603-0110206-x.

Yang SQ, Jing HW and Xu T (2014a) Mechanical behavior and failure analysis of brittle sandstone samples containing combined flaws under uniaxial compression. Journal of Central South University 21(5): 2059-2073, https://doi.org/10.1007/s11771-014-2155-5.

Yang SQ, Jing HW, Huang YH, Ranjith PG and Jiao YY (2014b) Fracture mechanical behavior of red sandstone containing a single fissure and two parallel fissures after exposure to different high temperature treatments. Journal of Structural Geology 69(A): 245-264, https://doi. org/10.1016/j.jsg.2014.10.014.

Yang SQ, Ranjith PG, Jing HW, Tian WL and Ju Y (2017) An experimental investigation on thermal damage and failure mechanical behavior of granite after exposure to different high temperature treatments. Geothermics 65: 180-197, https://doi.org/10.1016/j.geothermics.2016. 09.008

Yao W, Xu Y, Wang W and Kanopolous P (2016) Dependence of dynamic tensile strength of Longyou sandstone on heat treatment temperature and loading rate. Rock Mechanics and Rock Engineering 49(10): 3899-3915, https://doi.org/10.1007/s00603-015-0895-7.

Yoshitaka N, Naoki H, Tetsuro Y and Katsuhiko K (2010) Effects of relative humidity and temperature on subcritical crack growth in igneous rock. International Journal of Rock Mechanics and Mining Sciences 47(4): 640-646, https://doi.org/10.1016/j.ijrmms.2010.04. 009.

Yu QL, Ranjith PG, Liu HY et al. (2015) A mesostructure based damage mode for thermal cracking analysis and application in granite at elevated temperatures. Rock Mechanics and Rock Engineering 48(6) 2263-2282, https://doi.org/10.1007/s00603-014-0679-5.

Zhang W, Sun Q, Hao S, Geng J and Lü C (2016) Experimental study on the variation of physical and mechanical properties of rock after high temperature treatment. Applied Thermal Engineering 98: 1297-1304, https://doi.org/10.1016/j.applthermaleng.2016.01.010.

Zhang W, Sun Q and Zhang Y (2019) Effects of pre-existing cracks and temperature on failure mode of granite from Eastern China. Journal of Structural Geology 126: 330-337, https://doi.org/10.1016/j.jsg.2019. 06.018

Zhao Y, Feng Z, Xi B et al. (2011) Prospect of HDR geothermal energy exploitation in Yangbajing, Tibet, China, and experimental investigation of granite under high temperature and high pressure. Journal of Rock Mechanics and Geotechnical Engineering 3(3): 260-269, https://doi.org/10.3724/SP.J.1235.2011.00260.

Zhu T, Jing H, Su H et al. (2016) Physical and mechanical properties of sandstone containing a single fissure after exposure to high temperatures. International Journal of Mining Science and Technology 26(2): 319-325, https://doi.org/10.1016/j.ijmst.2015.12.019.

\section{How can you contribute?}

To discuss this paper, please submit up to 500 words to the editor at journals@ice.org.uk. Your contribution will be forwarded to the author(s) for a reply and, if considered appropriate by the editorial board, it will be published as a discussion in a future issue of the journal. 